\title{
Feeding Deterrent and Genotoxicity Analysis of a novel Phytopesticide by using Comet Assay against Helicoverpa armigera (HÜbner) (Lepidoptera: Noctuidae)
}

\author{
Soosaimanickam Maria Packiam ${ }^{1,2^{*}}$, Cyril Emmanuel ${ }^{3}$, Kathirvelu Baskar $^{2}$ and \\ Savarimuthu Ignacimuthu ${ }^{2}$ \\ ${ }^{I}$ Department of Biology; Loyola University Chicago; W. Sheridan, Illianois - USA. ${ }^{2}$ Entomology Research Institute; \\ Loyola College; Chennai - India. ${ }^{3}$ Global Hospitals and Health City; Chennai - India
}

\begin{abstract}
Newly developed Phytopesticidal formulations from pongam and neem oils were evaluated for their feeding deterrent activity using leaf disc choice and no-choice methods, and genotoxic study using comet assay against Helicoverpa armigera at different concentrations of 5, 10, 15, and 20 ppm. Among various phytopesticidal formulations, neem and pongam oils at 1:1 ratio, called PONNEEM showed significant feeding deterrent activity against $\mathrm{H}$. armigera at 20 ppm concentration and wasgenotoxic to $\mathrm{H}$. armigera $(P>0.001)$. The comet parameters, namely tail moment (arbitrary units), tail length $(\mu \mathrm{m})$ and tail DNA $(\%)$ were observed at all the concentrations of PONNEEM. Statistically significant changes in all the comet parameters of $\mathrm{H}$. armigera were observed at 20 ppm $(P<0.001)$. Feeding deterrent and genotoxicity effect of PONNEEM could be applied as phytopesticide for controlling the lepidopteran insect pests.
\end{abstract}

Key words: Genotoxicity, PONNEEM, Feeding deterrent, Helicoverpa armigera

\section{INTRODUCTION}

The indiscriminate use of synthetic pesticides in agricultural fields has resulted in serious environmental hazards (Singh et al. 2004; Singh et al. 2006; Shahi and Singh 2011), resurgence and outbreak of insect pests and in the development of resistance to insecticides. Due to the growing awareness of environmental pollution caused by the synthetic pesticides, alternate methods based on green pesticides are in demand (Mian and Mulla 1992; Singh et al. 1996; Baskar et al. 2009; Baskar et al. 2015).

Plants contain of numerous compounds, such as saponins, tannins, alkaloids, alkenyl phenols, and ditriterpenoids etc, which have insecticidal activity. A plant product exhibited strong feeding deterrent and insecticidal activity against $H$. armigera and $S$. litura, but it did not cause any toxic effects against the common carp (Baskar et al. 2014). Helicoverpa armigera (Hubner) is one of the major and polyphagous field insect pests. This insect pest is widely distributed in Asia, Africa, Austrialia, and Europe. It caused annual loss of about Rs. 2000 crore (Ignacimuthu and Jayarai 2003). It has developed resistance to various synthetic pesticides that are used to control the agricultural crops. The repeated use of synthetic pesticides has paved the way to harm not only the environment but also animals and human beings. Thus, there is need to find alternate and safe technologies for the insect pest management.

*Author for correspondence: mariaento@hotmail.com 
Use of nontoxic feeding deterrent plant based products, which kill the insect pests indirectly, could be an alternative method. Plant-based pesticides, known as phytopesticides, show good toxicity to many insect pests without phytotoxic effect. The phytopesticides are rich phytochemicals, which are effective in controlling insect pests in the place of synthetic insecticides (Georges et al. 2008). The identification of genotoxicity of the chemicals in the environment is carried out using comet assay or single cell gel electrophoresis (Kassie et al. 2000). The present study was aimed at assessing the feeding deterrent activity using the choice, and no-choice methods and genotoxicity effect of phytopesticide PONNEEM against $H$. armigera. This is the first report on the genotoxic effect of PONNEEM against $H$. armigera.

\section{MATERIAL AND METHODS}

\section{Preparation of Phytopesticidal Formulation}

The phytopesticidal formulation was prepared following Packiam and Ignacimuthu (2012).

\section{Insect culture}

Helicoverpa armigera larvae were collected from the bhendi field at Mangadu, Kancheepuram, Tamil Nadu, India. The larvae were reared at $27 \pm$ $2{ }^{\circ} \mathrm{C}$ in the insectary and allowed to multiply. They were fed with the standard artificial diet. The laboratory reared $3^{\text {rd }}$ instar larvae were used for the feeding deterrent activity using the choice, and nochoice methods and genotoxic effect using comet assay.

\section{Feeding deterrent activity}

Different phytopesticidal formulations were evaluated for their feeding deterrent activity using the choice method in the following manner. A stock concentration of $500 \mathrm{ppm}$ of fresh oil formulation was prepared by mixing with dechlorinated water. From the stock, 5, 10, 15, and $20 \mathrm{ppm}$ were prepared and tested against the third instar larvae of $H$. armigera. Fresh cotton (Gossypium sp.) leaf discs of 3-cm in diameter were punched using the cork borer; the leaf discs were dipped in 5, 10, 15 and $20 \mathrm{ppm}$ concentration. Leaf discs treated with nimbicidine served as reference control and those dipped in the emulsifier with water were considered as negative control. Treated leaf discs were placed in the Petri dish, having wet filter paper to avoid early drying of the treated leaf disc. In each Petri dish consisting control and treated leaf discs, single $3^{\text {rd }}$ instar larva of $H$. armigera was released individually for the choice method. For no-choice method, only treated leaf disc was kept in each Petri dish with $3^{\text {rd }}$ instar larva of $H$. armigera. Progressive consumption of leaf area by the larva after $24 \mathrm{~h}$ was recorded using leaf area meter (Delta-T Devices, Serial No. 15736 F96, UK). Leaf area eaten by the larvae in the treatment was corrected from the negative control. Ten replicates were maintained for each experiment with 10 larvae per replicate (total, $n=100$ ). The experiment was conducted under the laboratory conditions (27 $\pm 2^{\circ} \mathrm{C}$ ) with $75 \pm 5 \%$ relative humidity and $14: 10 \mathrm{~h}$ photoperiod.

The percentage of feeding deterrent index was calculated using the formula of Jannet et al. (2000).

$\begin{aligned} & \text { Antifeedant } \\ & \text { activity }\end{aligned}=\frac{\begin{array}{l}\text { Area protected } \\ \text { in control leaf }\end{array}-\begin{array}{l}\text { Area protected } \\ \text { in treated leaf }\end{array}}{\begin{array}{l}\text { Area protected } \\ \text { in control leaf }\end{array}+\begin{array}{l}\text { Area protected } \\ \text { in treated leaf }\end{array}} 100$

\section{DNA damage analysis}

\section{Experimental design}

Fresh cotton leaf (Gossypium sp.) was punched using cork borer; the leaf discs were dipped in 5, 10 and $20 \mathrm{ppm}$. Leaf discs treated with $5 \mathrm{mM}$ ethyl methanesulphonate EMS) was used as positive control; leaf discs dipped in the emulsifier with water were considered as negative control. Treated leaf discs were placed in the Petri dish having wet filter paper. In each Petri dish, single $3^{\text {rd }}$ instar larva of $H$. armigera was released individually for no-choice method. For each treatment, ten replicates were maintained. After $24 \mathrm{~h}$ of treatment, the larvae were reared continuously for three days to assess the DNA damage.

\section{Cell suspension preparation}

Fifty milligram of gut regions of $H$. armigera was taken from the treated with PONNEEM at 5, 10 and $20 \mathrm{ppm}$ concentrations, EMS $(5 \mathrm{mM})$ and normal insect and were ground with $2.0 \mathrm{~mL}$ of PBS using the mortar and pestle. The cells were mixed well in the vortex for $10 \mathrm{~min}$, then $2.0 \mathrm{~mL}$ of trypsin / EDTA was added and swirled to cover the monolayer of cells. It was incubated for at $37^{\circ} \mathrm{C}$ for $10 \mathrm{~min}$. The cells were dislodged by tapping to strike the side of the plate and checked under a microscope to ensure that all the cells were 
dislodged. Then $8.0 \mathrm{~mL}$ of cell medium containing fetal calf serum (FCS) was added. The cell suspension was transferred to a sterile centrifuge tube and centrifuged at $1000 \mathrm{x}$ g. The cell pellet was washed with PBS and the centrifugation was repeated. The cell pellet was re-suspended in Hank's balanced salt solution. The cell suspension was diluted with PBS (1:5) and counted by using haemocytometer.

\section{Viability assay for Single Cell Gel Electrophoresis} (SCGE)

Trypan blue dye (Pool-Zobel et al. 1993) was used to analyze the viability of cells of $H$. armigera. Living cells excluded the blue dye, whereas dead cells took it. The cells were counted using a light microscope (Olympus BX 60, Japan).

Comet Assay to assess DNA Damage in the cells of H. armigera

The cell suspension obtained was subjected to a comet assay according to the method of Singh et al. (1988). Seventy five microliter of $1 \%$ normal melting agarose in phosphate buffer saline at $65^{\circ} \mathrm{C}$ was poured gently onto fully frosted micro slides and covered immediately with a cover slip and placed over a frozen icepack for $5 \mathrm{~min}$. The cover slip was removed after the gel was set. The cell suspension $(10,000 / \mathrm{mL})$ was mixed with $1 \%$ low melting agarose at $37^{\circ} \mathrm{C}$. Seventy five microliter of the cell suspension was applied quickly on top of the gel, coated over the slide and allowed to set as before. A third coating of $75 \mu \mathrm{L}$ of $1 \%$ low melting agarose was done on the gel containing the suspended cell and allowed to set. Duplicate set of slides was prepared.

\section{Cell lysis}

After solidification of the Agarose, the cover slips were removed and the slides were immersed in the ice-cold lysis solution and kept in the refrigerator at $4{ }^{\circ} \mathrm{C}$ for at least $1 \mathrm{~h}$. All the above operations were performed in low lighting conditions in order to avoid additional cell damage. Slides were removed from the lysis solution and placed in an electrophoretic tank. The reservoirs were filled with the electrophoresis buffer until the slides were just immersed in it. Slides were allowed to stand in the buffer for about $20 \mathrm{~min}$, after which electrophoresis was carried out at $26 \mathrm{~V}$ for $10 \mathrm{~min}$. After electrophoresis, the slides were removed, washed three times in the neutralization buffer and gently tapped to dry. A few drops of the working solution of ethidium bromide were added on to the gel and the slide was covered with a cover slip.

\section{Image analysis}

The stained DNA in the cells was examined at 20 $\mathrm{x}$ magnification with the excitement $(460-590 \mathrm{~nm})$ under TE 2000 Nikon fluorescence microscope (Tokyo, Japan). The images of 50 randomly selected nuclei per slide were captured and analyzed using commercially available software (Comet Assay IV, UK www. perceptive.co.uk). The amount of damaged DNA migrated in the tail was expressed as percent of total fluorescence for each nucleus.

\section{Statistical analysis}

The feeding deterrent activity was subjected to the analysis of variance (ANOVA). Significant differences between the treatments were determined by DMRT $(\mathrm{P}<0.05)$. Differences between the groups were analyzed by the student's t-test using SPSS 11.0. Values were expressed as mean \pm SE. Data for the tail moment were statistically analyzed and presented in the figure as box as whisker plots, which represented the range (minimum and maximum, medians and $75^{\text {th }}$ percentile).

\section{RESULTS}

\section{Feeding deterrent activity}

Results showed that different phytopesticidal formulations inflicted different levels of deterrence in the feeding against $3^{\text {rd }}$ instar larvae of $H$. armigera in no-choice method (Table 1). Maximum feeding deterrent activity was recorded in the formulation $\mathrm{C}$ (PONNEEM consisting of pongam oil and neem oil at 1:1) at $20 \mathrm{ppm}$ (90.78\%), followed by at $15 \mathrm{ppm}(71.33 \%)$. The antifeedant activity of this phytopesticide was increased as the concentration increased. Leaves treated with different concentrations of PONNEEM showed the suppression of feeding by $H$. armigera under no-choice method. For the choice method, the results are presented in Table 2. Maximum feeding deterrant activity was observed in PONNEEM treated leaves at $5 \mathrm{ppm}$ $(75.02 \%)$ and $20 \mathrm{ppm}(87.22 \%)$ when compared to all other treatments. 
Table 1 - Per cent antifeedant activity of phytopesticidal formulations against $3^{\text {rd }}$ instar larvae of Helicoverpa armigera using no-choice method.

\begin{tabular}{lcccc}
\hline \multirow{2}{*}{ Treatments } & \multicolumn{3}{c}{ Concentration } \\
\cline { 2 - 5 } & $\mathbf{5 ~ p p m}$ & $\mathbf{1 0} \mathbf{~ p p m}$ & $\mathbf{1 5} \mathbf{~ p p m}$ & $\mathbf{2 0} \mathbf{~ p p m}$ \\
\hline Formulation A (Pongam oil + Neem oil - 3:7) & $24.35 \pm 2.74^{\mathrm{d}}$ & $36.54 \pm 1.52^{\mathrm{c}}$ & $47.64 \pm 3.98^{\mathrm{c}}$ & $64.42 \pm 6.86^{\mathrm{c}}$ \\
Formulation B (Pongam oil + Neem oil - 7:3) & $18.14 \pm 2.43^{\mathrm{b}}$ & $27.32 \pm 3.05^{\mathrm{b}}$ & $28.53 \pm 1.96^{\mathrm{b}}$ & $53.96 \pm 2.63^{\mathrm{b}}$ \\
Formulation C (PONNEEM) (Pongam oil + & $54.24 \pm 4.39^{\mathrm{e}}$ & $66.67 \pm 5.50^{\mathrm{e}}$ & $71.33 \pm 3.87^{\mathrm{e}}$ & $90.78 \pm 2.51^{\mathrm{e}}$ \\
Neem oil - 1:1) & $18.14 \pm 2.43^{\mathrm{b}}$ & $27.32 \pm 3.05^{\mathrm{b}}$ & $28.53 \pm 1.96^{\mathrm{b}}$ & $53.96 \pm 2.63^{\mathrm{b}}$ \\
Formulation D (Pongam oil) & $24.35 \pm 2.74^{\mathrm{d}}$ & $36.38 \pm 1.79^{\mathrm{c}}$ & $47.40 \pm 4.11^{\mathrm{c}}$ & $64.40 \pm 6.88^{\mathrm{c}}$ \\
Formulation E (Neem oil) & $21.73 \pm 1.99^{\mathrm{c}}$ & $44.66 \pm 5.48^{\mathrm{d}}$ & $55.10 \pm 1.73^{\mathrm{d}}$ & $68.86 \pm 4.91^{\mathrm{d}}$ \\
Formulation F (Nimbicidine) & $13.40 \pm 1.91^{\mathrm{a}}$ & $13.40 \pm 1.91^{\mathrm{a}}$ & $13.40 \pm 1.91^{\mathrm{a}}$ & $13.40 \pm 1.91^{\mathrm{a}}$ \\
Formulation G (Emulsifier control) & \multicolumn{3}{c}{}
\end{tabular}

Table 2 - Per cent antifeedant activity of phytopesticidal formulations against $3^{\text {rd }}$ instar larvae of Helicoverpa armigera using choice method. Mean \pm SD within columns followed by the same letter do not differ significantly using DMRT $\mathrm{P}<0.05)$.

\begin{tabular}{|c|c|c|c|c|c|c|c|c|}
\hline \multirow{3}{*}{ Treatments } & \multicolumn{8}{|c|}{ Concentration } \\
\hline & \multicolumn{2}{|c|}{5 ppm } & \multicolumn{2}{|c|}{10 ppm } & \multicolumn{2}{|c|}{15 ppm } & \multicolumn{2}{|c|}{20 ppm } \\
\hline & Treated & Control & Treated & Control & Treated & Control & Treated & Control \\
\hline Formulation A & 63.20 & 13.68 & 69.00 & 15.48 & 87.38 & 15.29 & 89.82 & 15.49 \\
\hline$($ Pongam oil + Neem oil $-3: 7)$ & $\pm 4.35^{\mathrm{d}}$ & $\pm .58^{c}$ & $\pm 4.45^{\mathrm{d}}$ & $\pm 1.21^{\mathrm{c}}$ & $\pm 3.67 \mathrm{f}$ & $\pm .95^{\mathrm{c}}$ & $\pm 2.88^{\mathrm{f}}$ & $\pm .86^{\mathrm{ab}}$ \\
\hline Formulation B & 59.67 & 13.49 & 62.42 & 14.52 & 64.45 & 14.33 & 73.68 & 15.22 \\
\hline$($ Pongam oil + Neem oil $-7: 3)$ & $\pm 2.70^{\mathrm{c}}$ & $\pm .16^{\mathrm{c}}$ & $\pm 4.95^{\mathrm{c}}$ & $\pm .56^{\mathrm{c}}$ & $\pm 4.41^{\mathrm{c}}$ & $\pm .49^{\mathrm{b}}$ & $\pm 6.10^{\mathrm{d}}$ & $\pm .55^{\mathrm{ab}}$ \\
\hline Formulation C (PONNEEM) & 75.02 & 10.05 & 77.66 & 11.19 & 80.36 & 12.18 & 87.22 & 15.84 \\
\hline$($ Pongam oil + Neem oil $-1: 1)$ & $\pm 5.05^{\mathrm{e}}$ & $\pm .29^{\mathrm{a}}$ & $\pm 4.80^{\mathrm{e}}$ & $\pm .52^{\mathrm{a}}$ & $\pm 8.66^{\mathrm{e}}$ & $\pm .53^{\mathrm{a}}$ & $\pm 9.43^{\text {ef }}$ & $\pm .602^{\mathrm{b}}$ \\
\hline \multirow[t]{2}{*}{ Formulation D (Pongam oil) } & 52.47 & 13.16 & 49.03 & 15.48 & 58.19 & 14.52 & 59.55 & 15.49 \\
\hline & $\pm 5.36^{\mathrm{b}}$ & $\pm .53^{\mathrm{c}}$ & $\pm 5.94^{\mathrm{b}}$ & $\pm 1.21^{\mathrm{c}}$ & $\pm 3.57 \mathrm{~b}$ & $\pm 1.22^{\mathrm{bc}}$ & $\pm 2.65^{\mathrm{b}}$ & $\pm .86^{\mathrm{ab}}$ \\
\hline \multirow[t]{2}{*}{ Formulation E (Neem oil) } & 59.20 & 12.24 & 60.59 & 13.00 & 59.72 & 14.06 & 65.51 & 14.48 \\
\hline & $\pm 1.35^{\mathrm{c}}$ & $\pm 1.56^{\mathrm{b}}$ & $\pm 5.16^{\mathrm{c}}$ & $\pm 2.24^{\mathrm{b}}$ & $\pm 4.96 \mathrm{~b}$ & $\pm .62^{\mathrm{b}}$ & $\pm 5.95^{\mathrm{c}}$ & $\pm .68^{\mathrm{a}}$ \\
\hline \multirow[t]{2}{*}{ Formulation F (Nimbicidine) } & 61.44 & 13.01 & 70.16 & 14.84 & 69.96 & 13.86 & 82.86 & 17.25 \\
\hline & $\pm 5.20^{\mathrm{cd}}$ & $\pm .46 b^{c}$ & $\pm 1.71^{\mathrm{d}}$ & $\pm .94^{\mathrm{c}}$ & $\pm 1.62^{\mathrm{d}}$ & $\pm .41^{\mathrm{b}}$ & $\pm 11.11^{\mathrm{e}}$ & $\pm 1.34^{\mathrm{c}}$ \\
\hline \multirow{2}{*}{$\begin{array}{l}\text { Formulation G (Emulsifier } \\
\text { control) }\end{array}$} & 21.07 & 21.07 & 21.07 & 21.07 & 21.07 & 21.07 & 21.07 & 21.07 \\
\hline & $\pm 1.892^{\mathrm{a}}$ & $\pm 1.89^{\mathrm{d}}$ & $\pm 1.89^{\mathrm{a}}$ & $\pm 1.89^{\mathrm{d}}$ & $\pm 1.89^{\mathrm{a}}$ & $\pm 1.89^{\mathrm{d}}$ & $\pm 1.89^{\mathrm{a}}$ & $\pm 1.89^{\mathrm{d}}$ \\
\hline
\end{tabular}

Comet assay to assess DNA damage in the cells of insects

PONNEM treated $3^{\text {rd }}$ instar larval DNA damages increased in the midgut cells of $H$. armigera depending on the concentrations (Fig. 1). The comet parameters, namely tail moment (arbitrary units), tail length $(\mu \mathrm{m})$ and tail DNA $(\%)$ were observed at all the concentrations of PONNEEM. Statistically significant changes in all the comet parameters of $H$. armigera were observed at 20 ppm $(\mathrm{P}<0.001)$. The tail moment data of the treated larvae of $H$. armigera showed a statistically significant increase depending on the increase in concentration. At 20 ppm concentration, the tail moment was equal to the standard (Table 3). The length of tail varied significantly between the concentration of control and treatment (10 and $20 \mathrm{ppm})$. A statistically significant increase was observed in the tail moment, tail length and tail DNA of midgut cells of $H$. armigera (Table 3 ). Thus, PONNEEM was genotoxic to $H$. armigera $(\mathrm{P}>0.001)$ above $10 \mathrm{ppm}$ concentration.

Table 3 - Effect of PONNEEM on comet parameters in the midgut cells of Helicoverpa armigera

\begin{tabular}{lccc}
\hline Group & Tail length $(\boldsymbol{\mu m})$ & Tail DNA $(\boldsymbol{\%})$ & Tail moment (arbitrary units) \\
\hline Control & $11.41 \pm 0.18$ & $10.26 \pm 0.03$ & $1.61 \pm 0.19$ \\
$5 \mathrm{mM} \mathrm{EMS}$ & $28.86 \pm 1.06^{\mathrm{a}}$ & $22.64 \pm 1.02^{\mathrm{a}}$ & $4.48 \pm 0.24^{\mathrm{a}}$ \\
$5 \mathrm{ppm}$ & $12.25 \pm 0.02^{\mathrm{b}}$ & $10.12 \pm 0.02^{\mathrm{b}}$ & $1.51 \pm 0.24^{\mathrm{a}}$ \\
$10 \mathrm{ppm}$ & $26.71 \pm 0.06^{\mathrm{a}}$ & $16.74 \pm 0.04^{\mathrm{a}}$ & $2.57 \pm 0.28^{\mathrm{c}}$ \\
$20 \mathrm{ppm}$ & $34.12 \pm 0.04^{\mathrm{a}}$ & $20.24 \pm 0.02^{\mathrm{a}}$ & $4.60 \pm 0.17^{\mathrm{a}}$ \\
\hline
\end{tabular}

Values are mean \pm S.E of three experiments; ${ }^{a} \mathrm{P}<0.001$ in comparison with control

${ }^{\mathrm{b}}$ Not significant in comparison with control; ${ }^{\mathrm{c}} \mathrm{P}<0.05$ in comparison with control 


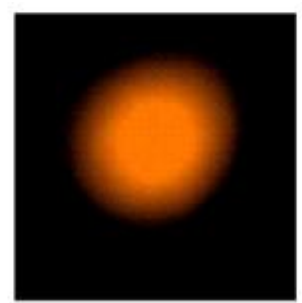

CONTROL



$5 \mathrm{ppm}$

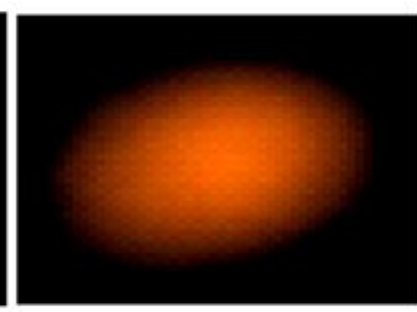

$10 \mathrm{ppm}$



$20 \mathrm{ppm}$

Figure 1 - Impact of PONNEEM on the tail moment of DNA in the midgut of Helicoverpa armigera.

\section{DISCUSSION}

Feeding Deterrent Activity: Feeding deterrent is a phyto chemical that inhibits feeding without killing the insect directly, while the insect remains near the treated foliage and dies through the starvation (Yasui et al. 1998). Most potent insect antifeedants are sesquiterpene lactones, diterpinoids, triterpinoids, quinoline and indole alkaloids (Schoonhoven 1982). At 20 ppm, PONNEEM exhibited $90.78 \%$ of antifeedant activity against $3^{\text {rd }}$ instar larvae of $H$. armigera. It clearly indicated that the active principles of karanjin and azadirachtin present in the PONNEEM inhibited larval feeding behaviour or made the food unpalatable or the substances directly acted on the chemosensilla of the larva, resulting in feeding deterrence due to synergistic effect. These results corroborated with the findings of Morimoto et al. (2002), Susurluk et al. (2007), Pavela (2010), and Duraipandiyan et al. (2015) who reported that the botanicals possessed similar type of feeding deterrent activity against $S$. litura. Antifeedant played a major role in the unsuitability of non-host plants as food for the insects. In the present investigation, the combination of pongam and neem formulation (1:1) exhibited very good result in controlling lepidopteran insect pests. In the present study PONNEEM exhibited the feeding deterrent and genotoxicity effect on $H$. armigera. Baskar et al. (2015) reported that semipurified compounds exhibited toxicity to $S$. litura; which acted as protein inhibitor and damaged the midgut cells. PONNEEM exhibited the insecticidal and histopatholgical changes of $H$. armigera and it was not toxic to Rattus norvegicus (Packiam et al. 2013).

\section{DNA Damage Analysis}

The single cell gel electrophoresis (SCGE)/comet assay is one of the standard methods for assessing the DNA damage with applications in genotoxicity testing, biomonitoring, molecular epidemiology and ecogenotoxicology. This assay is adapted for its simplicity, sensitivity, versatility and economy. The comet assay is widely accepted for the environmental biomonitoring and has been successfully applied in assessing soil pollution using freshwater planaria (Guecheva et al. 2001). The similar findings were reported for zebra mussels (Pavlica et al. 2001) in Mytilus edulis L. (Pruski and Dixon 2002). In the present investigation, the genotoxicity of PONNEEM, a newly developed phytopesticide was studied using the comet assay. So far, there was not much work performed on the genotoxicity of phytopesticide against lepidopteran pests using comet assay. An effort was made to analyze the toxic effect of active principles of pongam and neem oils on the cells of $H$. armigera using single cell gel electrophoresis (comet assay). Third instar larvae of $H$. armigera, which were exposed to PONNEEM showed a significant increase in DNA damage in the cells of midgut at different concentrations. The results coincided with other studies (Gaivao et al. 1999; Kar Chowdhuri et al. 2001; Nazir et al. 2003) who evaluated the toxicological analysis on Drosophila using comet assay.

In this study, severe DNA damage was observed at 20 ppm concentration but a dose-dependent DNA damage wasobserved in all the comet parameters, $v i z$. , tail moment (arbitrary units), tail length $(\mu \mathrm{m})$ and tail DNA (\%). All the comet parameters of treated midgut cells of $H$. armigera depended on the concentrations of PONNEEM due to the active principles, viz. karanjin and azadirachtin. 
Azadirachtin when taken up into the cells, lowers protein synthesis and also inhibits cell division. Such effects are seen in flaccid paralysis of muscles, midgut cells necrosis and loss of nidi cells of the gut and lack of midgut enzyme production (Rembold and Annadurai 1993). Direct toxic effects were observed on different tissues and cells (Nasiruddin and Mordue 1993), which added complexity to the variety of physiological events azadirachtin could affect. This study showed the usefulness of the modified method for the SCGE/comet assay for the evaluation of in vivo genotoxicity of PONNEEM in $\mathrm{H}$. armigera larvae.

\section{ACKNOWLEDGEMENTS}

Funding for this work was provided by Entomology Research Institute, Loyola College, Chennai, Tamilnadu, India.

\section{REFERENCES}

Baskar K, Duraipandiyan V, Ignacimuthu S. Bioefficacy of the triterpenoid friedelin against Helicoverpa armigera (Hub.) and Spodoptera litura (Fab.) (Lepidoptera: Noctuidae). Pest Manag Sci. 2014; 70: 1877-1883.

Baskar K, Kingsley S, Vendan SE, Paulraj MG, Duraipandian V, Ignacimuthu S. Antifeedant, larvicidal and pupicidal activities of Atalantia monophylla (L) Correa against Helicoverpa armigera Hubner (Lepidoptera: Noctuidae). Chemosphere. 2009; 75: 355-359.

Baskar K, Ignacimuthu S, Jayakumar M. Toxic Effects of Couroupita guianensis against Spodoptera litura (Fabricius) (Lepidoptera: Noctuidae). Neotrop Entomol. 2015; 44: 84-91.

Duraipandiyan V, Baskar K, Muthu C, Ignacimuthu S, Al-Dhabi NA. Bioefficacy of Flindersine against Helicoverpa armigera Hübner, Spodoptera litura Fabricius, Anopheles stephensis Liston. and Culex quinquefasciatus Say. Braz Arch Biol Technol. 2015; http://dx.doi.org/10.1590/S1516-8913201500282

Gaivao I, Sierra LM, Comendador MA. The w/w+ SMART assay of Drosophila melanogaster detects the genotoxic effects of reactive oxygen species inducing compounds. Mutat Res. 1999; 440: 139-145.

Georges K, Jayaprakasam B, Dalavoy SS, Nair MG. Pest managing activities of plant extracts and anthraquinones from Cassia nigricans from burkina Faso. Bioresource Technol. 2008; 99: 2037-2045.
Guecheva T, Henriques JA, Erdtmann B. Genotoxic effect of freshwater planarian in vivo studied with the single cell gel test (Comet assay). Mutat Res. 2001; 497: 19-27.

Ignacimuthu S, Jayaraj S. Ecofriendly approaches for sustainable pest management. Curr Sci. 2003; 84: 1025.

Jannet HB, Skhiri HF, Mighri Z, Simmonds MSJ, Blaney WM. Responses of Spodoptera littoralis larvae to Tunisian plant extracts and to neo-clerodane diterpenoids isolated from Ajuga pseudoiva leaves. Fitoterapia. 2000; 71: 105-112.

Kar Chowdhuri D, Nazir A, Saxena DK. Effect of three chlorinated pesticides on hsrw stress gene in transgenic Drosophila melanogaster. J Biochem Mol Toxicol. 2001; 15: 173-186.

Kassie F, Parzefall W, Knasmiiler S. Single cell gel electrophoresis assay: a new technique for human biomonitoring studies. Mutat Res. 2000; 463: 13-31.

Mian SL, Mulla MS. Effects of pyrethroid insecticides on non target invertebrates in aquatic ecosystem. $J$ Agric Entomol. 1992; 2: 73-98.

Morimoto M, Tanimoto K, Saktani A, Komai K. Antifeedant activity of an anthrquinone aldehydes in Galium aparine L. against Spodoptera litura F. Phytochem. 2002; 60: 163-166.

Nasiruddin M, Mordue AJ. The effect of azadirachtin on the midgut histology of the locusts, Schistocerca gregaria and Locusta migratoria. Tissue Cell. 1993; 25: 875-884.

Nazir A, Mukhopadhyay I, Saxena DK, Chowdhuri D. Evaluation of toxic potential of captan: Induction of hsp70 and tissue damage in transgenic Drosophila melanogaster (hsp70-lacZ) Bg9. J Biochem Mol Toxicol. 2003;17: 98-107.

Packiam SM, Baskar K, Ignacimuthu S. Insecticidal and histopathological effects of botanical formulations against Helicoverpa armigera (Hub.) (Lepidoptera: Noctuidae). J Agric Technol. 2013; 9: 573-583.

Packiam SM, Ignacimuthu S. Effect of PONNEEM on Spodoptera litura (Fab.) and Its Compatibility with Trichogramma chilonis Ishii. Braz Arch Biol Technol. 2012; 22: 291-298.

Pavela R. Antifeedant activity of plant extracts on Leptinotarsa decemLineata Say. and Spodoptera littoralis Bois. larvae. Ind Crop Prod. 2010; 32: 213219.

Pavlica M, Klobucar GI, Mojas N, Erben R, Papes D. Detection of DNA damage in haemocytes of zebra mussel using comet assay. Mutat Res. 2001; 490: 209-214.

Pool-Zobel BL, Guigas C, Klein RC, Neudecker CH, Renner HW, Schmezer P. Assessment of genotoxic effects by lindane. Food Chem Toxicol. 1993; 31: 271-283. 
Pruski AM, Dixon DR. Effects of cadmium on nuclear integrity and DNA repair effciency in the gill cells of Mytilus edulis L. Aquatic Toxicol. 2002; 57: 127-137.

Rembold H, Annadurai RS. Azadirachtin inhibits proliferation of Sf9 cells in monolayer culture. Z Naturforsch. 1993; 48: 495-499.

Schoonhoven LM. Biological aspects of antifeedants. Ent Exp Appl. 1982; 31: 57-69.

Shahi J, Singh A. Effect of bioactive compounds extracted from euphorbias plants on haematological and biochemical parameters of Channa punctatus. Rev Inst Med Trop Sao Paulo. 2011; 53: 259-263.

Singh A, Singh DK, Misera TN. Molluscicide of plant origin. Biol Agric Hortic. 1996;13: 205-52.

Singh A, Singh SK, Yadav RP, Srivastava VK, Singh D, Tiwari S. Eco-friendly molluscicides, piscides and insecticides from common plants. In: Livingston JV, (Ed.). Trends in Agriculture and soil pollution research. New York: Nova Science. 2006; pp. 2005230 .
Singh SK, Tripathi PK, Yadav RP, Singh D, Singh A. Toxicity of malathion and carbaryl pesticides effects on some biochemical profiles of the freshwater fish Colisa fusciatus. Bull Environ Contam Toxicology. 2004; 72: 592-599.

Susurluk H, Caliskan Z, Gurkan O, Kirmizigul S, Goren N. Antifeedant activity of some Tanacetum species and bioassay guided isolation of the secondary metabolities of Tanacetum cadmeum ssp. Cadmeum (Composittae). Ind Crop Prod. 2007; 26: 220-228.

Received: March 15, 2015; Accepted: May 19, 2015. 